\title{
Antioxidative Effects of Cornis fructus Extract on Chromium Trioxide Toxicity
}

\author{
Young-Mi Seo \\ Department of Nursing, College of Medicine, Wonkwang Health Science University, Iksan, Korea
}

\section{Chromium Trioxide의 독성에 대한 산수유 추출물의 항산화 효과}

서영미

원광보건대학교 간호학과

\begin{abstract}
This study examined the antioxidative effects of Cornis fructus (CF) extract on cultured C6 glioma cells. For this purpose, cytotoxicity analysis of chromium trioxide $\left.\mathrm{C} \mathrm{CO}_{3}\right)$ was performed and the protective effects of the $\mathrm{CF}$ extract on $\mathrm{CrO}_{3}$-induced cytotoxicity was examined after the $\mathrm{C} 6$ glioma cells were cultured for 48 hours. The antioxidative effects, such as electron donating activity (EDA) and lactate dehydrogenase (LDH) activity were also analyzed. In this study, $\mathrm{CrO}_{3}$ decreased the cell viability in a dose dependent manner. The $\mathrm{XTT}_{50}$ value was determined to be $33 \mu \mathrm{M}$ after the cells were treated for 48 hours at a concentrations of $20 \sim 40 \mu \mathrm{M} \mathrm{CrO}$. The catalase (CAT) antioxidant increased significantly the cell viability that had been decreased by $\mathrm{CrO}_{3}$-induced cytotoxicity. Regarding the protective effect of the CF extract, the cell viability of the CF extract was increased significantly compared to that of $\mathrm{CrO}_{3}$ only. In addition, the CF extract showed antioxidative effects, such as EDA and an inhibitory effect on the LDH activity. These findings suggest that the cytotoxicity of $\mathrm{CrO}_{3}$ is correlated with oxidative stress, and the CF extract effectively prevented $\mathrm{CrO}_{3}$-induced cytotoxicity through the antioxidative effects. In conclusion, natural products, such as the CF extract may be a useful therapeutic agent for the prevention or treatment of toxicity induced by heavy metals via oxidative stress.
\end{abstract}

Key words: Antioxidative effect, Cytotoxicity, Natural products, Oxidative stress

This is an Open Access article distributed under the terms of the Creative Commons Attribution Non-Commercial License (http://creativecommons.org/licenses/by-nc/4.0) which permits unrestricted non-commercial use, distribution, and reproduction in any medium, provided the original work is properly cited.

Copyright @ 2018 The Korean Society for Clinical Laboratory Science. All rights reserved.
Corresponding author: Young-Mi Seo Department of Nursing, College of Medicine, Wonkwang Health Science University, 514 Iksan-daero, Iksan 54538, Korea Tel: 82-63-840-1314 Fax: 82-63-840-1319

E-mail:dudn0408@wu.ac.kr

Received: May 15, 2018 Revised: May 27, 2018 Accepted: May 28, 2018

\section{서 론}

크롬을 비롯한 납, 수은과 같은 중금속류는 인체에 노출되면, 배출이 어려울 뿐만 아니라 체내에 축적된 후에는 각 기관의 혈 관을 통해 여러 장기에 손상을 초래하게 된다[1]. 크롬은 아말감 을 비롯한 시멘트제조나 도금, 내화벽돌 및 화학비료제조 등 여 러 산업 공정에 널리 사용되어 왔다[2]. 그러나 독성이 강해 인체 가잦은 노출에 폭로될 경우 심각한 질환을 일으키는 것으로 잘
알려져 있다[1]. 특히, 뇌조직과 같이 혈액-뇌장벽(bloodbrain barrier, $\mathrm{BBB}$ )이 잘 형성된 경우는 크롬이나수은 및 카드 뮴과 같은 중금속이 직접 뇌실질을 통과하기 어렵지만, 이들이 분진이나 흄(fume)에 의해 피부를 통해 체내로 들어온 경우, 혈 액을 통해 허파를 비롯한 위, 신장 및 뇌조직 등 다양한 장기에 침투함으로서 각종 질환을 유발한다는 것은 이미 잘 알려져 있 다[3]. 특히, 6 가 크롬은 3가 크롬과는 달리 생체막을 쉽게 통과 할 뿐만 아니라 독성이 매우 강하기 때문에 발암성과 돌연변이 
성이 높아 취급 시 각별한 주의가 요구된다[4]. 그러나, 현재 구 강 또는 호흡을 통한 크롬 중독 시 환원제인 vitamin C의 투여나 기관지확장제와 같은 처치 외에는 특별한 치료방법이 없는 실 정이다[4]. 최근, 크롬의 독성이 산화적 손상(oxidative stress) 과 직접적인 연관성이 있다고 제시되면서 크롬 중독에 의한 치 료를 항산화 측면에서 접근하려는 시도가 이루어지고 있다[5]. 그러나 이에 대한 연구는 초기단계일 뿐만 아니라 연구가 많이 이루어지지 않아 매우 미흡한 상태이다[2]. 특히, 산화적 손상은 세포내 핵 전사 인자(nuclear transcription factor)인 NF-kB (nuclear factor $\mathrm{kB}$ )를 활성화시켜 세포 고사인자(apoptosis factor)를 활성화 시키는 동시에[6], 세포막의 N-methyl-D aspartate (NMDA) 수용체를 과 활성시킨다[7]. 또한 막지질의 과산화[8] 및 활성질소(reactive nitrogen species, NOS)와 활 성산소(reactive oxygen species, ROS)간의 상호작용에 의한 peroxynitrite라는 강력한 독성물질을 형성함으로서 세포를 퇴 화 내지는 사멸에 이르게 한다[9]. 최근, 각종 식물에는 항산화 를 비롯한 항암, 항독, 항염 등에 유용한 다양한 생리활성성분들 이 많이 함유되어 있다고 알려지고 있다[10]. 특히, 식물 중 산수 유(Cornis fructus, CF)는 층층나무과(Cornaceae)에 속하는 낙엽관목으로 우리나라 전역에서 자생하고 있다. 산수유는 3 4월에 잎보다 황색꽃이 먼저 피는데 8 10월경에는 붉게 열매 를 맺으며 이의 생약명으로는 육조나 석조라고도 부른다[11]. 산수유는 cornin을 비롯한 loganin, linolic acid, saponin, gallic acid와 같은 성분들을 함유하고 있다. 특히, linoleic acid 나 gallic acid와 같은 성분은 항산화에 유효한 생리활성성분으 로 잘 알려져 있다[12]. 따라서, 산수유는 오래전부터 항균이나 항바이러스를 비롯한 다뇨증이나 월경과다 및 면역증강 등의 치료에 사용되어 왔다[13]. 그러나 아직까지 산수유의 항산화 에 대한 연구는 소수에 불과하다[11]. 근래, 세포배양법이 발전 되면서 이를 이용한 병변의 기전규명이나 약제의 안전성 검사 및 신약에 대한 효능 등을 세포수준에서 규명하려는 연구가 활 발히 이루어지고 있다[14]. 더욱이, 시험관내(in vitro) 정량적 분석방법이 개발되면서 정확하면서도 빠르고 간편하게 분석할 수 있는 계기가 마련되었다[15]. 본 연구는 중금속의 일종인 $\mathrm{CrO}_{3}$ 의 독성을 산화적 손상과 관련하여 조사함과 동시에 이의 중독 시 천연소재로부터 치료할 수 있는 물질을 항산화 측면에 서 규명함으로서 병변치료에 유효한 새로운 물질의 탐색을 행 하고자 시행하였다.

\section{재료 및 방법}

\section{1. 세포주}

본 실험에 사용한 신경아교세포인 C6 glioma 세포주는 American Type Culture Collection (ATCC, Maryland, USA) 에서 분양 받아 사용하였다.

\section{2. 약제 제조}

사용시약으로는 catalase (CAT)를 비롯한 chromium trioxide $\left(\mathrm{CrO}_{3}\right)$, ethyl alcohol, ethylenediaminetetraacetic acid (EDTA), trypsin, 1,1-diphenyl-2-picrylhydrazyl (DPPH), phosphate buffered saline (PBS), dimethyl sulfoxide (DMSO) 및 2,3-bis-(2-methoxy-4-nitro-5-sulfophenyl)2H-tetra-zolium-5-carboxanilide (XTT)는 Sigma-Alderich 사(Sigma Chemical, Saint Louis, MO, USA.)에서 구입하였다. 또한, Hanker's balanced salt solution (HBSS)과 fetal bovine serum (FBS) 및 minimum essential medium (MEM)은 Gibco 사(Gibco Chemical, USA)에서 구입하였다. Lactate dehydrogenase (LDH) CytoTox detection kit는 Takara사(Takara Biomedicals, Seoul, Korea)에서 구입하였다. $\mathrm{CrO}_{3}$ 의 제조는 $\mathrm{FBS}$ 가 들어 있지 않은 $\mathrm{MEM}$ 을 사용하여 각각 $10 \mathrm{uM}, 50 \mathrm{uM}$ 및 $100 \mathrm{uM}$ 의 저장액을 만들어 냉암소에 저장한 후 필요시 희석하 거나 또는 배양액에 직접 첨가하여 사용하였다. XTT는 $\mathrm{PBS}$ 를 이용하여 $50 \mathrm{ug} / \mathrm{mL}$ 의 저장액을 만든 후 냉암소에 보관한 다음 필요한 양을 직접 배양액에 첨가하여 사용하였다.

\section{3. 세포 배양}

C6 glioma 세포의 배양은 Kim 등[16]의 방법에 따라 trypsin 을 이용한 효소 해리술로 배양용기에 부착된 세포를 분리하였 다. 분리된 세포들은 튜브에 모아 원침시킨 후 $10 \% \mathrm{FBS}$ 가 함유 된 MEM 배양액으로 $1 \times 10^{5}$ cells/well이 되도록 96-well 배양 용기에 분주하였다. 분주된 세포들은 $36^{\circ} \mathrm{C}, 5 \% \mathrm{CO}_{2} / 95 \% \mathrm{air}$ 로 조절된 항온기 내에서 72 시간 동안 배양한 후 실험에 사용하였다.

\section{4. 산수유 추출}

산수유는 전초를 채취하여 깨끗이 씻은 후 햇빛이 들지 않고 서늘한 곳에서 건조시켜 일정한 크기로 잘라 냉암소에 보관하 여 시료로 사용하였다. 추출을 위하여 보관중인 시료 $250 \mathrm{~g}$ 을 이의 3 배량의 물과 함께 $1,000 \mathrm{~mL}$ 의 환저 플라스크에 넣고 24 시간 동안 가열하였다. 이를 3회 반복적으로 행한 후 추출액을 모아 $3,000 \mathrm{rpm}$ 에서 20분간 원침하였다. 원침 완료 후 여과하 
여 진공농축기로 감압 농축한 다음 24 시간 동안 동결건조기에서 건조하여 $13 \mathrm{~g}$ 의 시료를 얻었다. 이 때 수율은 $5.2 \%$ 로 나타났다.

\section{5. 세포생존율 조사}

세포생존율의 분석은 Mosmann [17]의 방법에 따라 행하였 다. 즉, 배양이 완료된 세포를 well당 $1 \times 10^{5} /$ well의 밀도로 분 주한 후 72 시간 동안 배양하였다. 배양이 완료된 세포에 약제나 시료를 처리한 다음, 전날 제조한 XTT를 각 well당 $10 \mathrm{uL}$ 씩을 넣고 $37^{\circ} \mathrm{C}, 5 \% \mathrm{CO}_{2} / 95 \%$ air로 조절된 항온기 내에서 4 시간 동 안 배양하였다. 배양 완료 후 DMSO로 처리하여 $450 \mathrm{~nm}$ 에서 ELISA reader (Spectra max 250, Molecular Devices, Sunnyvale, USA)로 흡광도를 측정하여 대조군과 비교 조사하 였다.

\section{6. $\mathrm{CrO}_{3}$ 에 대한 세포독성 조사}

$\mathrm{CrO}_{3}$ 의 세포독성 조사를 위하여 배양 세포에 20 40 uM의 $\mathrm{CrO}_{3}$ 가 각각 포함된 배양액에서 48시간 동안 배양한 후 $450 \mathrm{~nm}$ 에서 ELISA reader로 흡광도를 측정하여 대조군과 비교 조사하 였다.

\section{CAT의 항산화능 측정}

CAT의 항산화능을 조사하기 위하여 $\mathrm{H}_{2} \mathrm{O}_{2} 40 \mathrm{uM}$ 를 배양 세 포를 처리하기 2시간 전에 CAT가 $20 \mathrm{uM}$ 과 $40 \mathrm{uM}$ 이 포함된 배 양액에서 세포를 처리한 후 세포생존율을 대조군과 비교 조사 하였다.

\section{8. $\mathrm{CrO}_{3}$ 에 대한 항산화제의 영향}

$\mathrm{CrO}_{3}$ 의 독성에 대한 항산화제의 일종인 CAT의 영향을 알아 보기 위하여 $\mathrm{XTT}_{50}$ 농도의 $\mathrm{CrO}_{3}$ 를 배양 세포에 처리하기 2시간 전에 CAT가 각각 $20 \mathrm{uM}$ 과 $40 \mathrm{uM}$ 이 포함된 배양액에서 배양한 후 세포생존율을 $\mathrm{CrO}_{3}$ 만의 처리와 비교 조사하였다. $\mathrm{XTT}_{50}$ 값 은 직선 회귀식에 의하여 산출하였다.

\section{9. $\mathrm{CrO}_{3}$ 에 대한 산수유 추출물의 영향}

$\mathrm{XTT}_{50}$ 농도의 $\mathrm{CrO}_{3}$ 를 배양 세포에 처리하기 2시간 전에 산 수유 추출물이 각각 $140 \mathrm{ug} / \mathrm{mL}$ 과 $160 \mathrm{ug} / \mathrm{mL}$ 가 들어 있는 배 양액에서 배양한 후 세포생존율을 $\mathrm{CrO}_{3}$ 로만 처리한 세포와 비 교 조사하였다

\section{0. 전자공여활성(electron donating activity, EDA) 측정}

$\mathrm{EDA}$ 는 항산화물질에 대한 라디칼 소거활성을 측정하는 손
쉬운 측정물이다. 항산화물질에 대한 항산화 효과를 측정하기 위해 $\mathrm{EDA}$ 에 의한 환원력을 사용한다. EDA 측정은 Blois [18]의 방법에 따라 행하였다. 즉, 메탄올시료에 $0.3 \mathrm{mM} \mathrm{DPPH}$ 메탄올 용액 $100 \mathrm{uL}$ 를 첨가하여 실온에서 30 분간 처리하였다. 처리 후 ELISA reader로 $517 \mathrm{~nm}$ 에서 흡광도를 측정하였다. 전자공여 능은 시료 첨가군과 시료 무첨가군간의 차이를 시료 무첨가군 에 의한 백분율로 나타냈으며, 또한 CAT의 활성을 양성대조군 으로 사용하였다.

\section{Lactate dehydrogenase (LDH) 활성 측정}

$\mathrm{LDH}$ 측정을 위하여 약제나 시료를 처리한 세포의 배양액을 모은 후 $1,500 \mathrm{rpm}$ 에서 15 분 동안 원침시킨 다음 상등액 $50 \mathrm{uL}$ 를 취하였다. 취한 상등액에 LDH kit 반응액 $50 \mathrm{uM}$ 을 넣고 30 분간 반응시켰다. 반응 완료 후 ELISA reader로 $450 \mathrm{~nm}$ 에서 흡 광도를 측정하여 대조군과 비교 조사하였다. $\mathrm{LDH}$ 활성은 대조 군에 대한 백분율로 표시하였다.

\section{2. 통계 처리}

실험의 모든 자료는 3 회 이상 반복한 결과를 mean $\pm \mathrm{SD}$ 로 나 타냈으며, 실험결과는 SPSS (Win Version 18.0, SPSS, Chicago, $\mathrm{USA}$ )를 이용하여 군간의 차이를 비교하기 위하여 ANOVA를 시 행하였다. 사후 분석은 Tukey's HSD (honest significant difference)로 하였으며, 모든 통계의 유의수준은 $P$-value가 0.05 미만의 경우를 유의한 것으로 채택하였다.

\section{결 과}

\section{1. $\mathrm{CrO}_{3}$ 의 세포독성 측정}

$\mathrm{CrO}_{3}$ 에 대한 세포독성을 측정하기 위하여 배양세포에 20 $40 \mathrm{uM}$ 의 $\mathrm{CrO}_{3}$ 가 들어 있는 배양액으로 각각 처리한 결과, $20 \mathrm{uM}$

Table 1 . The cytotoxicity of chromium trioxide $\left(\mathrm{CrO}_{3}\right)$ in cultured C6 glioma cells

\begin{tabular}{llllll}
\hline $\begin{array}{l}\text { Incubation of } \\
(\mu \mathrm{M})\end{array}$ & $\mathrm{CrO}_{3}$ & XTT assay $(450 \mathrm{~nm})$ & & & \\
\cline { 2 - 2 } & Mean $\pm \mathrm{SD}$ & & & \\
\hline Control & $0.21 \pm 0.02$ & & 60.51 & $<0.001$ \\
20 & $0.14 \pm 0.01$ & & & \\
30 & $0.12 \pm 0.01$ & & \\
40 & $0.07 \pm 0.00$ & & \\
$\mathrm{XTT}_{50}\left(\mathrm{CrO}_{3}\right)$ & $0.11 \pm 0.01$ & & & \\
\hline
\end{tabular}

The values are mean $\pm S D(N=16)$.

Abbreviation: XTT, 2,3-bis-(2-methoxy-4-nitro-5-sulfophenyl)$2 \mathrm{H}$-tetra-zolium-5-carboxanilide. 


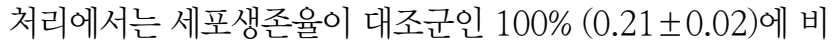
하여 66.7\% (0.14 \pm 0.01)로 나타났으며 $30 \mathrm{uM}$ 에서 처리한 경 우 57.1\% (0.12 \pm 0.01$)$ 로 나타났다. 또한, $40 \mathrm{uM}$ 의 경우 세포 생존율은 $33.3 \%(0.07 \pm 0.00)$ 로 나타났다. 이 과정에서 $\mathrm{XTT}_{50}$ 값은 $33 \mathrm{uM}$ 에서 나타났다 $\left(P<0.001\right.$ ) (Table 1). $\mathrm{CrO}_{3}$ 에 대한 세포독성에 따른 사후분석 결과 세포생존율이 대조군, $\mathrm{CrO}_{3}$ $20 \mathrm{uM}, \mathrm{CrO}_{3} 30 \mathrm{uM}, \mathrm{CrO}_{3} 33 \mathrm{uM}, \mathrm{CrO}_{3} 40 \mathrm{uM}$ 순으로 높음을 알 수 있었다. 다만 $\mathrm{CrO}_{3} 20 \mathrm{uM}, \mathrm{CrO}_{3} 30 \mathrm{uM}, \mathrm{CrO}_{3} 33 \mathrm{uM}$ 은 통계적으로 유의한 차이는 아니었다.

\section{CAT의 항산화능 측정}

CAT의 항산화능 조사 결과, $\mathrm{H}_{2} \mathrm{O}_{2} 40 \mathrm{uM}$ 만의 처리에서는 세 포생존율이 대조군에 비하여 $45.0 \%$ (0.09 \pm 0.02$)$ 로 나타났다 $(P<0.001)$. 그러나, 세포생존율이 CAT $20 \mathrm{uM}$ 의 처리에서는

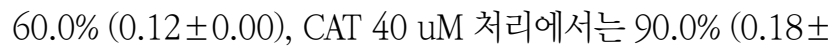
$0.02)$ 로 나타났다 $(P<0.001)$ (Table 2). CAT의 항산화능에 대 한 사후분석 결과 대조군과 CAT $40 \mathrm{uM}, \mathrm{CAT} 20 \mathrm{uM}$ 과 $\mathrm{H}_{2} \mathrm{O}_{2}$ $40 \mathrm{uM}$ 순으로 세포생존율이 높음을 알 수 있었다.

\section{3. $\mathrm{CrO}_{3}$ 의 세포독성에 대한 항산화제의 영향}

$\mathrm{CrO}_{3}$ 의 세포독성에 대한 항산화제의 영향을 알아본 결과, $\mathrm{XTT}_{50}$ 농도인 $\mathrm{CrO}_{3}$ 만의 처리에서 39.5\% (0.68 \pm 0.10$)$, CAT

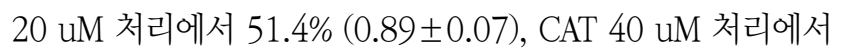

Table 2. The antioxidative activity of catalase (CAT) on the hydrogen peroxide $\left(\mathrm{H}_{2} \mathrm{O}_{2}\right)$ in cultured $\mathrm{C} 6$ glioma cells

\begin{tabular}{|c|c|c|c|}
\hline \multirow{2}{*}{$\begin{array}{c}\text { Concentrations of CAT } \\
(\mu \mathrm{M})\end{array}$} & XTT assay $(450 \mathrm{~nm})$ & \multirow{2}{*}{$\mathrm{F}$} & \multirow{2}{*}{$P$} \\
\hline & Mean \pm SD & & \\
\hline Control & $0.20 \pm 0.01$ & 35.97 & $<0.001$ \\
\hline $40 \mathrm{H}_{2} \mathrm{O}_{2}$ & $0.09 \pm 0.02$ & & \\
\hline 20 & $0.12 \pm 0.00$ & & \\
\hline 40 & $0.18 \pm 0.02$ & & \\
\hline
\end{tabular}

The values are mean $\pm S D(N=16)$.

Abbreviation: See Table 1.

Table 3. The effect of catalase (CAT) on the cytotoxicity induced by chromium trioxide $\left(\mathrm{CrO}_{3}\right)$ in cultured $\mathrm{C} 6$ glioma cells

\begin{tabular}{|c|c|c|c|}
\hline \multirow{2}{*}{$\begin{array}{c}\text { Concentrations of CAT } \\
(\mu \mathrm{M})\end{array}$} & XTT assay (450 nm) & \multirow{2}{*}{$\mathrm{F}$} & \multirow{2}{*}{$P$} \\
\hline & Mean \pm SD & & \\
\hline Control & $1.72 \pm 0.03$ & 128.38 & $<0.001$ \\
\hline $\mathrm{XTT}_{50}\left(\mathrm{CrO}_{3}\right)$ & $0.68 \pm 0.10$ & & \\
\hline 20 & $0.89 \pm 0.07$ & & \\
\hline 40 & $1.25 \pm 0.05$ & & \\
\hline
\end{tabular}

The values are mean $\pm S D(N=16)$. Abbreviation: See Table 1.
$72.7 \%$ (1.25 \pm 0.05$)$ 로 통계적으로 유의한 차이를 보였다 $(P<$ 0.001) (Table 3). $\mathrm{CrO}_{3}$ 의 세포독성과 항산화제의 영향에 따른 사후검정결과 대조군, CAT $40 \mathrm{uM}, \mathrm{CAT} 20 \mathrm{uM}, \mathrm{XTT}_{50}\left(\mathrm{CrO}_{3}\right)$ 순으로 세포생존율이 높음을 알 수 있었다.

\section{4. $\mathrm{CrO}_{3}$ 의 세포독성에 대한 산수유추출물의 영향}

산수유 추출물이 $\mathrm{CrO}_{3}$ 의 세포독성에 미치는 영향을 조사한 결과 $\mathrm{CrO}_{3}$ 만의 처리에서의 세포생존율은 대조군인 $100 \%$ (1.83 \pm 0.03$)$ 에 비하여 $41.5 \%(0.76 \pm 0.07)$ 로 낮게 나타났다. 반면, $140 \mathrm{ug} / \mathrm{mL}$ 산수유 추출물 처리에서의 세포생존율은 $52.5 \%(0.96 \pm 0.08)$, 산수유 추출물 $160 \mathrm{ug} / \mathrm{mL}$ 의 처리에서는 $62.8 \%(1.15 \pm 0.05)$ 로 나타났다 $(P<0.001)$ (Table 4). 산수유 추출물이 $\mathrm{CrO}_{3}$ 의 세포독성에 미치는 영향에 대한 사후검정결 과 대조군, 산수유 $160 \mathrm{ug} / \mathrm{mL}$, 산수유 $140 \mathrm{ug} / \mathrm{mL}, \mathrm{XTT}_{50}$ $\left(\mathrm{CrO}_{3}\right)$ 순으로 세포생존율이 높은 것을 알 수 있었다.

\section{EDA 측정}

전자공여활성(EDA)의 측정결과 산수유 추출물 $140 \mathrm{ug} / \mathrm{mL}$ 농도에서는 대조군에 비하여 활성이 $80.4 \%(1.23 \pm 0.09)$ 로 나 타났으며, 산수유 추출물 $160 \mathrm{ug} / \mathrm{mL}$ 농도에서는 $77.8 \%$

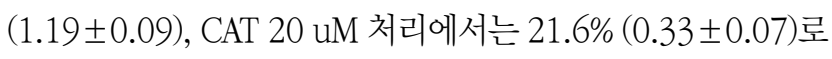
점차 감소한 것으로 나타났다(Table 5). 따라서, 산수유 추출물

Table 4. The protective effect of Cornis fructus (CF) extract on chromium trioxide $\left(\mathrm{CrO}_{3}\right)$-induced cytotoxicity in cultured $\mathrm{C} 6$ glioma cells

\begin{tabular}{|c|c|c|c|}
\hline \multirow{2}{*}{$\begin{array}{l}\text { Concentrations of CF } \\
\text { extract }(\mathrm{ug} / \mathrm{mL})\end{array}$} & XTT assay $(450 \mathrm{~nm})$ & \multirow{2}{*}{$\mathrm{F}$} & \multirow{2}{*}{$P$} \\
\hline & Mean \pm SD & & \\
\hline Control & $1.83 \pm 0.03$ & 168.78 & $<0.001$ \\
\hline $\mathrm{XTT}_{50}\left(\mathrm{CrO}_{3}\right)$ & $0.76 \pm 0.07$ & & \\
\hline 140 & $0.96 \pm 0.08$ & & \\
\hline 160 & $1.15 \pm 0.05$ & & \\
\hline
\end{tabular}

The values are mean $\pm S D(N=16)$.

Abbreviation: See Table 1.

Table 5. The electron donating activity (EDA) of Cornis fructus (CF) extract

\begin{tabular}{lcccc}
\hline \multirow{2}{*}{$\begin{array}{c}\text { Concentrations of CF } \\
\text { extract }(\mathrm{ug} / \mathrm{mL})\end{array}$} & EDA $(517 \mathrm{~nm})$ & & $P$ \\
\cline { 2 - 3 } & Mean \pm SD & & \\
\hline Control & $1.53 \pm 0.06$ & & $130.58<0.001$ \\
20 CAT & $0.33 \pm 0.07$ & & \\
140 & $1.23 \pm 0.09$ & & \\
160 & $1.19 \pm 0.09$ & & \\
\hline
\end{tabular}

The values are mean $\pm S D(N=16)$.

Abbreviation: CAT, catalase; See Table 1. 


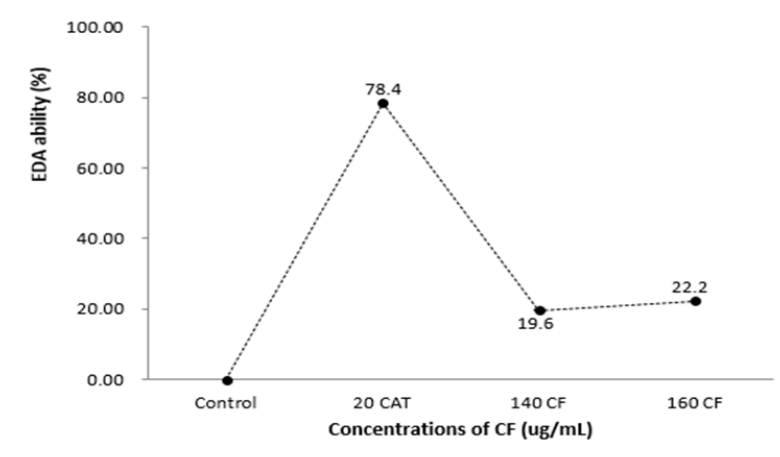

Figure 1. Electron donating ability of CF extract at concentrations of $140 \mathrm{ug} / \mathrm{mL}$ and $160 \mathrm{ug} / \mathrm{mL}$, respectively. The data indicate the mean for 3 times on triplicate experiments. Electron donating activity of CF extract were significantly different from negative control. CAT was used as positive control.

Table 6. The lactate dehydrogenase (LDH) activity of Cornis fructus (CF) extract on chromium trioxide $\left(\mathrm{CrO}_{3}\right)$-induced cytotoxicity in cultured C6 glioma cells

\begin{tabular}{|c|c|c|c|}
\hline \multirow{2}{*}{$\begin{array}{l}\text { Concentrations of CF } \\
\text { extract (ug/mL) }\end{array}$} & LDH activity (450 nm) & \multirow{2}{*}{$\mathrm{F}$} & \multirow{2}{*}{$P$} \\
\hline & Mean \pm SD & & \\
\hline Control & $1.76 \pm 0.04$ & 35.56 & $<0.001$ \\
\hline $\mathrm{XTT}_{50}\left(\mathrm{CrO}_{3}\right)$ & $2.40 \pm 0.07$ & & \\
\hline 140 & $2.13 \pm 0.13$ & & \\
\hline 160 & $1.86 \pm 0.07$ & & \\
\hline
\end{tabular}

The values are mean $\pm \mathrm{SD}(\mathrm{N}=16)$.

Abbreviation: See Table 1, 4.

$140 \mathrm{ug} / \mathrm{mL}$ 와 $160 \mathrm{ug} / \mathrm{mL}$ 의 전자공여능은 각각 $19.6 \%$ 와 $22.2 \%$, CAT $20 \mathrm{uM}$ 의 전자공여능은 $78.4 \%$ 로 대조군에 비하여 통계적으로 유의하였다 $(P<0.001)$ (Figure 1). 전자공여능의 사후검정결과 CAT $20 \mathrm{uM}$, 산수유 추출물 $160 \mathrm{ug} / \mathrm{mL}$ 와 140 $\mathrm{ug} / \mathrm{mL}$, 대조군 순으로 높은 것으로 나타났다.

\section{6. $\mathrm{LDH}$ 활성 측정}

$\mathrm{CrO}_{3}$ 의 세포독성에 대한 산수유 추출물의 $\mathrm{LDH}$ 활성을 조사 한 결과 $\mathrm{CrO}_{3}$ 만의 처리에서는 $\mathrm{LDH}$ 활성이 대조군인 $100 \%$ (1.76 \pm 0.04$)$ 에 비하여 $136.4 \%(2.40 \pm 0.07)$ 로 매우 높게 나타 났다. 이에 비하여, $140 \mathrm{ug} / \mathrm{mL}$ 산수유 추출물 처리에서는 $\mathrm{LDH}$ 활성이 $121.0 \%$ (2.13 \pm 0.13$)$ 로 나타나 $\mathrm{CrO}_{3}$ 만의 처리에 비하 여 매우 감소한 것을 확인하였다 $(P<0.001)$ (Table 6). 또한, $160 \mathrm{ug} / \mathrm{mL}$ 의 산수유 추출물 처리에서는 $105.7 \%(1.86 \pm 0.07)$ 로 $\mathrm{CrO}_{3}$ 만의 처리에 비하여 유의한 $\mathrm{LDH}$ 활성 감소를 보였다 $(P<$ 0.001) (Figure 2). $\mathrm{CrO}_{3}$ 의 세포독성에 대한 산수유 추출물의 $\mathrm{LDH}$ 활성에 대한 사후검정 결과 대조군과 $160 \mathrm{ug} / \mathrm{mL}$ 산수유 추출물, $140 \mathrm{ug} / \mathrm{mL}$ 산수유 추출물, $\mathrm{CrO}_{3}$ 처리군 순으로 $\mathrm{LDH}$

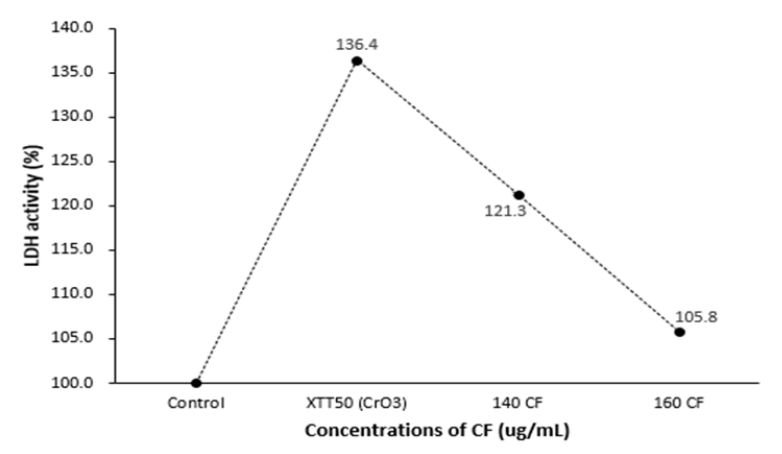

Figure 2. The LDH activity of CF extract at concentrations of 140 $\mathrm{ug} / \mathrm{mL}$ and $160 \mathrm{ug} / \mathrm{mL}$, respectively. The data indicate the mean for 3 times on triplicate experiments. LDH activity of CF extract were significantly different from negative control. $\mathrm{CrO}_{3}$ was used as positive control.

활성 감소가 높은 것으로 나타났다.

\section{고 찰}

크롬을 비롯한 중금속의 성분은 인체에서 소량으로 존재하 면서 생명에 필요한 물질을 구성하고 있지만 다량이 인체 내에 축적되면 심한 중독을 유발하여 각종 부작용을 일으키고 있다 [19]. 본 연구에서는 삼산화크롬인 $\mathrm{CrO}_{3}$ 의 세포독성을 조사하 기 위하여 배양 C6 glioma 세포에 20 40 uM의 $\mathrm{CrO}_{3}$ 를 48시 간 동안 처리한 결과 처리농도에 비례하여 세포생존율이 대조 군에 비해 유의한 감소를 보였다. 이 과정에서 $\mathrm{XTT}_{50}$ 값이 100 $\mathrm{uM}$ 이하인 $33 \mathrm{uM}$ 로 나타나 Borenfreund와 Puerner [20]에 의한 독성판정기준에 의해 고독성(highly-toxic)인 것으로 나 타났다. 본 연구 결과는 $\mathrm{CrO}_{3}$ 가 세포독성을 가지고 있음을 말해 주고 있으며 Jung 등[21]에 의한 $\mathrm{CrO}_{3}$ 의 세포독성을 보고한 결 과와 일치하였다. 이 같은 현상은 $\mathrm{CrO}_{3}$ 가 세포 내 핵산물질인 DNA (deoxyribonucleic acid)의 합성방해나 또는 단백질의 합성을 억제한 결과도 배제할 수는 없지만[3], 그 보다는 $\mathrm{CrO}_{3}$ 의 산화적 손상에 의해 세포가 퇴화 내지는 고사한 결과일 가능 성이 클 것으로 생각된다. 따라서, 본 연구에서는 $\mathrm{CrO}_{3}$ 의 독성 과 산화적 손상과의 연관성을 조사하였다. 항산화제의 일종인 $\mathrm{CAT}$ 를 배양 세포에 전 처리한 결과, 처리한 CAT의 처리 농도에 비례하여 $\mathrm{CrO}_{3}$ 에 의해 감소된 세포생존율을 유의하게 증가시 켰다. 본 결과는 $\mathrm{CrO}_{3}$ 의 독성이 산화적 손상과 관련이 있음을 제시하고 있으며, Jung 등[21]이 $\mathrm{CrO}_{3}$ 의 독성을 항산화제인 vitamin E가 방어하였다는 연구 결과와도 상호 일치함을 알 수 있었다. 이 같은 현상은 $\mathrm{CrO}_{3}$ 에 의해 생성된 hydroxyl radical 이나 superoxide anion radical과 같은 자유라디칼을 CAT나 
vitamin E와 같은 항산화제가 제거한 결과인 것으로 생각된다 [4]. 한편, 산수유 추출물이 $\mathrm{CrO}_{3}$ 의 독성에 미치는 영향을 알아 보기 위하여 산수유 추출물 $140 \mathrm{ug} / \mathrm{mL}$ 와 $160 \mathrm{ug} / \mathrm{mL}$ 를 배양 세포에 각각 전 처리한 결과, $\mathrm{CrO}_{3}$ 만의 처리에 비하여 유의한 세포생존율의 증가를 보였다. 본 결과는 산수유 추출물이 $\mathrm{CrO}_{3}$ 에 의한 산화적 손상을 방어한 결과임을 말해주고 있으며, 이는 동시에 산수유 추출물의 항산화능을 제시하고 있다. 이의 증거 하나로서 Lee 등[22]이 산수유 추출물이 자유라디칼인 과산화 수소 $\left(\mathrm{H}_{2} \mathrm{O}_{2}\right)$ 의 산화적 손상을 방어하였다는 연구 결과와도 일치 한다. 이 같은 현상은 산수유 추출물 속에 함유된 linolic acid를 비롯한 gallic acid 및 saponin과 같은 항산화 성분의 상호작용 의 결과에 기인한 것으로 생각된다[12]. 따라서, 본 연구에서는 산수유 추출물의 항산화능을 알아보기 위하여 전자공여활성 $(\mathrm{EDA})$ 을 비롯한 $\mathrm{LDH}$ 활성을 조사하였다. 본 연구의 $\mathrm{EDA}$ 측정 을 위해 $140 \mathrm{ug} / \mathrm{mL}$ 와 $160 \mathrm{ug} / \mathrm{mL}$ 의 산수유 시료를 처리한 결 과 대조군에 비하여 유의한 전자공여능의 증가를 보였다. 이는 산수유 추출물이 자유기제거능이 있음을 말해주고 있으며 이는 곧 산수유 추출물의 항산화능을 증명해 주고 있다. 한편,산수유 추출물의 LDH 활성조사 결과에서 $140 \mathrm{ug} / \mathrm{mL}$ 와 $160 \mathrm{ug} / \mathrm{mL}$ 의 산수유 추출물 처리에서는 $\mathrm{CrO}_{3}$ 로만의 처리에 비하여 유의한 $\mathrm{LDH}$ 활성저해를 보였다. 위 결과는 산수유 추출물의 항산화능 에 의하여 $\mathrm{CrO}_{3}$ 의 산화적 손상으로 야기되는 막의 지질과산화 가 방어된 것으로서, 이는 산수유 추출물이 과산화수소에 의한 산화적 손상을 방어하여 LDH 활성감소를 나타냈다는 연구 보 고와도 일치하였으며[22], EDA와 함께 산수유 추출물의 항산 화능을 증명하고 있음을 알 수 있다. LDH 활성분석은 지질과산 화반응(reaction of lipid peroxidation)의 분석과 함께 막의 손 상 정도를 측정할 수 있는 정량적 분석방법의 하나로 알려져 있 다[8]. 이상의 결과로부터 산수유 추출물은 산화적 손상과 관련 이 있는 $\mathrm{CrO}_{3}$ 의 독성을 항산화능에 의하여 효과적으로 방어한 다는 것을 확인하였다. 따라서, 산수유 추출물과 같은 천연성분 에 대한 항산화적 생리활성 분석은 질병치료를 위한 약제의 부작 용 염려는 물론 나아가서 치료적 효능이 높은 물질성분을 이용해 산화적 손상으로 야기되는 질환 치료적 측면에서 새로운 물질 개발을 위한 기초자료로서의 활용도가 높을 것으로 생각된다.

\section{요 약}

본 연구 목적은 산수유 추출물의 항산화 효과를 배양 C6 glioma 세포를 대상으로 조사하였다. 이 같은 목적을 위하여 C6 glioma 세포를 48시간 동안 배양한 후 6가 크롬의 세포독성
및 산수유 추출물의 방어효과를 조사하였다. 이외에 $\mathrm{EDA}$ 및 $\mathrm{LDH}$ 활성과 같은 항산화 효과를 분석하였다. 본 연구에서 $\mathrm{CrO}_{3}$ 는 처리농도에 비례하여 세포생존율을 감소시켰다. 또한 이 과정에서 세포를 48시간 동안 20 40 uM로 각각 포함된 배 양액에서 처리한 결과 XTT 50 값은 $33 \mathrm{uM}$ 로 나타났다. 항산화 제인 $\mathrm{CAT}$ 는 $\mathrm{CrO}_{3}$ 로 유도된 세포독성에 의해 감소된 세포생존 율을 유의하게 증가시켰다. 한편 산수유 추출물의 보호효과에 있어서, 산수유 추출물은 $\mathrm{CrO}_{3}$ 만의 처리군에 비하여 세포생존 율을 유의하게 증가시켰다. 동시에 산수유 추출물은 $\mathrm{EDA}$ 와 $\mathrm{LDH}$ 활성과 같은 항산화 효과를 보였다. 이와 같은 결과로부터 $\mathrm{CrO}_{3}$ 의 독성에 산화적 손상이 관련되어 있는 것으로 나타났다. 또한 산수유 추출물은 이의 항산화 효과에 의하여 $\mathrm{CrO}_{3}$ 의 세포 독성을 효과적으로 방어하였다. 결론적으로, 산수유 추출물과 같은 천연소재는 산화적 손상과 관련된 중금속에 의해 유발된 세포독성을 방어 내지는 치료하는데 유용한 치료적 요소의 하 나로 생각된다.

Acknowledgements: This paper was supported by Wonkwang Health Science University in 2018.

Conflict of interest: None

\section{REFERENCES}

1. Pattison DI, Davies MJ, Levina A, Dixon NE, Lay PA. Chromium (VI) reduction by catecholamines results in DNA cleavage in vitro: relevance to chromium genotoxicity. Chem Res Toxicol. 2001;14:500-510. http://dx.doi.org/10.1021/tx000229s.

2. Tso TC, Lai HJ, Yang JL. Effects of mannitol or catalase on the generation of reactive oxygen species leading to DNA damaged by chromium (VI) reduction with ascorbate. Chem Res Toxicol. 1999;12:1002-1009. http://dx.doi.org/10.1021/tx9802264.

3. Zhang Q, Kluz T, Salnikow K, Costa M. Comparison of the cytotoxicity, cellular uptake, and DNA-protein induced by potassium chromate in lymphoblast cell line derived three different individuals. Biol Trace Elem Res. 2002;86:11-22.

4. Leonard S, Wang S, Zang L, Castranova V, Vallyathan V, Shi X. Role of molecular oxygen in the generation of hydroxyl and superoxide anion radicals during enzymatic $\mathrm{Cr}$ (VI)-induced carcinogenesis. J Environ Pathol Toxicol Oncol. 2000;19: 49-60.

5. Bagchi D, Bagchi M, Stohs SJ. Chromium (VI)-induced oxidative stress, apoptosis cell death and modulation of p53 tumor suppressor gene. Mol Cell Biochem. 2001;222:149-158.

6. Gracia-Lopez D, Cuevas MJ, Almar M, Lima E, De-Paz JA, Gonzalez-Gallego J. Effects of eccentric exercise on NF-kB activation in blood mononuclear cells. Med Sci Sport Exerc. 2007; 39:653-664. http://dx.doi.org/10.1249/mss.0b013e31802f04f6.

7. Jung IJ. The effect of NMDA/glycin receptor antagonist, 
7-chlorokynurenic acid on cultured astrocytes damaged by ischemia-like condition. J Exp Biomed Sci. 2009;15:355-362.

8. Hah DS, Kim CH, Kim GS, Kim EG, Kim JS. Antioxidant effects of traditional medicinal plants on lipid peroxidation. Kor J Ver Res. 2005;45:341-350.

9. Endoh M, Maiese K, Wanger J. Expression of the inducible from of nitric oxide synthase by reactive astrocytes after transient global ischemia. Brain Res. 1994;651:92-100. http://doi.org/ 10.1016/0006-8993(94)90683-1.

10. Kim TY, Jekal SJ. Antioxidative effect of Chelidonium majus extract on cultured NIH3T3 fibroblasts injured by cadmium chloride of toxicant. Kor J Clin Lab Sci. 2016;48:1-7. http:// doi.org/10.15324/kjcls. 2016.48.1.1.

11. Peng Q, Wei Z, Lau BH. Cornis fructus enhances endothelial cell antioxidant defenses. General Pharmacol. 1998;31:221-225. http://doi.org/10.1016/S0306-3623(97)00459-X.

12. Shahrzad SK, Aoyagi A, Winter A, Koyama I, Bitsch B. Pharmacokinetics of gallic acid and its relative bioavailability from tea in healthy humans. J Nutrition. 2001;131:1207-1210. http://doi.org/10.1093/jn/131.4.1207.

13. Sun J, Chu YF, Wu X, Liu RH. Antioxidant and antiproliferative activities of common fruits. J Agric Food Chem. 2002; 50:7449-7454.

14. Oh YL, Choi YR, Chang BS, Jung IJ. Antioxidative effect of Portulaca oleracea L. extract on allergic contact dermatitis agent, copper in cultured human skin fibroblasts. J. Invest. Cosm. 2012;8:243-249.

15. Gates MA, Tworoger SS, Hecht JL, De-Vivo I, Rosner B,
Hankinson SE. A prospective study of dietary flavonoid intake and incidence of epithelial ovarian cancer. Int J Cancer. 2007; 121:2225-2232. http://doi.org/10.1002/ijc.22790.

16. Kim MS, Seo YM, Park ST. Antioxidant effect of kaempferol on cultured human skin fibroblasts damaged by methyl mercuric chloride. J Kor Soc People Plants Environ. 2010;13:23-29.

17. Mosmann T. Rapid colorimetric assay for cellular growth and survival: application to proliferation and cytotoxicity assays. J Immunol Meth. 1983;65:55-63. http://doi.org/10.1016/00221759(83)90303-4.

18. Blois MS. Antioxidant determination by the use of a stable free radical. Nature. 1958;26:1199-1200. http://doi.org/10.1038/ $1811199 \mathrm{a} 0$.

19. Park ST, Lim KT, Chung YT, Kim SU. Methylmercury-induced neurotoxicity in cerebral neuron culture is blocked by antioxidants and NMDA receptor antagonist. Neurotoxicol. 1996;17:37-45.

20. Borenfreund E, Puerner A. A simple quantitative procedure using monolayer culture of cytotoxicity assay (HTD/NR-90). J Tiss Cult Meth. 1985;9:7-9.

21. Jung JY, Oh SK, Park SH, Yoon MY, Yu YW, Rim YS, et al. Antioxidative effect of Ajugamultiflora BUNGE extract on chromium trioxide, dermatitis inducer in cultured NIH3T3 fibroblast. J Invest Cosm. 2014;10:1-6.

22. Lee JK, Hong GY, Park YJ, Park ST. Effect of Cornis fructus extract on the cell adhesion ability and oxidative stress in cultured NIH3T3 fibroblasts injured by hydrogen peroxide. J Kor Soc People Plants Environ. 2008;11:49-57. 